J. Perinat. Med. 9 (1981) 79

\section{On the incidence of errors in large epidemiology studies with comments on evaluation, interpretation, and future surveys}

\author{
E. P. Issel, H. Eggers, G. Hofmann, U. Krüger, G. Scheinpflug
}

From the Department of Obstetrics-Gynecology (Charité), Humboldt University, Berlin (Chairman: Prof. Dr. med. habil. H. Bayer) and the Department of Pediatrics, Wilhelm-Pieck University, Rostock (Chairman: Prof. Dr. sc. med. J. Külz)
It is a well known disadvantage of small, yet exact, epidemiological studies that their statistical evaluations have limits because of the low number of cases in certain categories. Furthermore, there is always the risk that the material inspite of the best advance planning is not representative for generalizations.

For this reason, larger studies with case numbers of over 5000 are carried out increasingly. These have special problems for evaluations, the causes of which are related to the considerable work and the large number of required staff:

1.) Errors in coding occur more frequently.

2.) Within a large study variables which allow to some degree subjective classification are being valued differently depending upon the variability of the investigators bias. This occurs even if standard interpretation have been agreed to.

\section{Material and method}

For the study project "Perinatology"* in the years 1970 to 19726780 questionnaires and examination forms on the epidemiology of newborns at risk [1] were completed from eight institutions for obstetrics and pediatrics in six cities of the GDR. The 56 page booklet contained 338 criteria, which could be coded indenpendent from each other. The data were obtained 1 . from a post- partum interview of the mother; 2 . from the case records; and 3. examination of the newborn. Some valuations of various clinical and sociological questions have already been published [2, 3]. The processing of the data was done by means of computer cards magnetic tape, tabular or single case printouts (medium computer R300, GDR manufacture). We have used two methods to analyze and evaluate errors.

1.1 Control of errors in $\mathbf{3 1 0}$ cases. From the 1927 cases in the University of Berlin, Women's and Children's Hospital (Charité) we selected 310 cases radomly distributed over three years. We evaluated 33 criteria which are routinely and unequivocially recorded in the hospital records. For evaluation we compared the data from the computer printout with those in the original hospital records. Any difference in the documentation of these findings was counted as error. A total of 10,230 statements $(310 \times 33)$ were checked which could either be correct or incorrect.

In addition the errors were classified as to the degree of possible elimination within the epidemiologic study.

1.) Errors which cannot be corrected by tabular evaluation. They always influence the validity of the results. They occur from the incorrect coding of findings. 
2.) Errors which may be eliminated for tabular evaluation by appropriate programing. This computational elimination reduces the number of cases usable for evaluation. These errors are missing codes for findings in the questionnaires, numberical coding without corresponding key and erroneous confusion of "no therapy" with "not stated."

\subsection{Comparison of frequency of unusual findings at various hospitals.}

All criteria for which the coding requires a certain subjective classification by the examiner were tabulated for each of the institutions. For illustration of the purpose of this study we publish seven of these criteria as examples. As can be seen from Tabs. IV and V, there were seven criteria obtained from the clinical examination of newborns. For this set of data the differences of the occurrence of abnormal findings between the medical facilities were most notable.

In Tabs. III-V the institutions are identified with the numbers 1 to 8 . Because of the low number of cases the percent values in Tab. IV regarding abnormalities in low birth weight infants $(<2501$ grams) was rounded to whole numbers.

\section{Results}

Tab. I summarizes all errors. The total number of discovered discrepancies between hospital records and computer printouts was quite high with $8.8 \%$.

Tab. I. Tabulation of all errors found when comparing computer printouts and case histories.

\begin{tabular}{llrc}
\hline & & Absolute & Percent \\
\hline Coded & Total & 10,230 & 100 \\
& Correct & 9,328 & 91.2 \\
& Incorrect & 902 & 8.8
\end{tabular}

Errors which can be eliminated by suitable programing

$$
422 \quad 4.3
$$

Errors which cannot be eliminated and which influence the final statement

$$
460
$$

Tab. II correlates the errors with criteria for which they were found. We wish to comment on those errors which can be eliminated, specifically on four criteria with particularly high error rates.

Criterion 33 (Administration of antibiotics to the newborn): "No administration" was erronously coded as "not stated," in addition it was evidently evaluated superficially so that no statements were derived from this item. A similar error was frequently made for criterion 23 (occurrence of irregular antibodies during pregnancy), 2 (discharge home of the infant or transfer to another hospital) and 7 (time elapsed until normalization of pathological 1 minute APGAR score). Since for these items the code "not stated" dealt only with normal cases, the validity was not impaired.

In regard to eliminable errors we offer comments on those seven criteria for which error rates exceeded $5 \%$ and which may lead to erronous conclusions.

Criterion 29 (Position and presentation of the fetus during birth): Occipito-anterior and occipitoposterior vertex presentations were confused. Thus, occipital posterior position, an anomaly, cannot be evaluated.

Criterion 30 (Fever during delivery): The agreed upon classifications were not adhered to exactly. Thus, the statement was reduced to "yes" or "no." Criterion 26 (Onset of labor) and Criterion 27 (Quality of contractions): There was a lack of differentiation between the use of labor enhancing medications for induction of labor and application for the treatment of poor concentrations after spontaneous onset of labor.

Criterion 19 (Number of previous deliveries): There was a poor choice of recording key for "no preceeding delivery" the code was " 1 :" Thus, for the number of preceeding births the key was numerically greater by one; this was occasionally overlooked. Therefore, for tabulation some 2parae were added to the primiparae.

Criterion 20 (Toxemia of pregnancy): Transient blood pressure changes with peaks in the pathological range were erronously coded as toxemia.

Criterion 9 (Occupation of the mother): Differences between computer printout and entry in the case history were not considered errors because information in the patient's record is rather 
Tab. II. Tabulation of errors found in the tested criteria.

\begin{tabular}{|c|c|c|c|c|c|c|c|}
\hline & Criterion & \multicolumn{2}{|c|}{$\begin{array}{l}\text { Eliminable } \\
\text { Errors } \\
\text { Absolute } \\
\qquad[\%]\end{array}$} & \multicolumn{2}{|c|}{$\begin{array}{l}\text { Non-eliminable } \\
\text { Errors } \\
\text { Absolute } \\
\qquad \mid \%]\end{array}$} & \multicolumn{2}{|c|}{$\begin{array}{l}\text { Total } \\
\text { Absolute } \\
\text { [\%] }\end{array}$} \\
\hline 1. & Infant's birth date & - & - & - & - & - & - \\
\hline 2. & Discharge or transfer of infant & 14 & 4.5 & 1 & 0.3 & 15 & 4.8 \\
\hline 3. & Birth weight & 1 & 0.3 & 12 & 3.9 & 13 & 4.2 \\
\hline 4. & Length & 1 & 0.3 & 5 & 1.6 & 6 & 1.9 \\
\hline 5. & Sex & 2 & 0.6 & 6 & 1.9 & 8 & 2.6 \\
\hline 6. & 1 minute APGAR score & $\overline{1}$ & 0.3 & 13 & 4.2 & 14 & 4.5 \\
\hline 7. & Normalization of pathological APGAR score & 19 & 6.1 & 13 & 4.2 & 32 & 10.3 \\
\hline 8. & Maternal age & 1 & 0.3 & 6 & 1.9 & 7 & 2.2 \\
\hline 9. & Maternal occupation & 2 & 0.6 & 22 & 7.0 & 24 & 7.7 \\
\hline 10. & Single or multiple pregnancy & 2 & 0.6 & 1 & 0.3 & 3 & 1.0 \\
\hline 11. & Maternal diabetes mellitus & 2 & 0.4 & 3 & 1.0 & 5 & 1.6 \\
\hline 12. & Maternal cardiac disease & 1 & 0.3 & 3 & 1.0 & 4 & 1.3 \\
\hline 13. & Maternal renal disease & 3 & 0.3 & 10 & 3.2 & 13 & 4.2 \\
\hline 14. & Maternal pulmonary disease & 5 & 1.6 & 3 & 1.0 & 8 & 2.6 \\
\hline 15. & Maternal thyroid disease & 4 & 1.3 & 3 & 1.0 & 7 & 2.2 \\
\hline 16. & Other maternal diseases & - & - & 15 & 4.8 & 15 & 4.8 \\
\hline 17. & Previous gynecological surgery & 4 & 1.3 & 9 & 2.9 & 13 & 4.2 \\
\hline 18. & Prevous abortions & 2 & 0.6 & 9 & 2.9 & 11 & 3.5 \\
\hline 19. & Previous births & 1 & 0.3 & 29 & 9.4 & 30 & 9.7 \\
\hline 20. & Toxemia of pregnancy & 2 & 0.6 & 29 & 9.4 & 31 & 10.0 \\
\hline 21. & Anemia during pregnancy & 4 & 1.3 & 10 & 3.2 & 14 & 4.5 \\
\hline 22. & Hemorrhage during second half of pregnancy & 1 & 0.3 & 8 & 2.6 & 9 & 2.9 \\
\hline 23. & Irregular antibodies & 53 & 17.2 & 2 & 0.6 & 55 & 17.9 \\
\hline 24. & Amniotic fluid assessment & 3 & 1.0 & 14 & 4.5 & 17 & 5.4 \\
\hline 25. & Time of ruptured membranes & - & - & 6 & 1.9 & 6 & 1.9 \\
\hline 26. & Onset of labor & 3 & 1.0 & 39 & 12.6 & 42 & 13.6 \\
\hline 27. & Quality of contraction & 1 & 0.3 & 39 & 12.6 & 40 & 12.9 \\
\hline 28. & Method of delivery & 1 & 0.3 & 3 & 1.0 & 4 & 1.3 \\
\hline 29. & Presentation of fetus at birth & 3 & 1.0 & 77 & 24.6 & 80 & 25.6 \\
\hline 30. & Fever during delivery & 6 & 1.9 & 66 & 21.0 & 72 & 22.9 \\
\hline 31. & Cephalhematoma & 3 & 1.0 & 5 & 1.6 & 8 & 2.5 \\
\hline 32. & Exchange transfusion & - & - & 4 & 1.3 & 4 & 1.3 \\
\hline 33. & Administration of antibiotics to the newborn & 296 & 95.6 & 3 & 1.0 & 299 & 96.6 \\
\hline
\end{tabular}

global while statements from the interview of the mother is much more detailed and reflects reality more correctly.

Tabs. III-V list the results of the comparison of various criteria according to the frequency of unexpected findings in the various institutions. Tab. III lists two criteria which serve to identify the infant as "at risk neonate". This study admitted an increased number of at-risk newboms. It is remarkable that the variance for the birth weight (low birth weight between $7.7 \%$ and $14.5 \%$ ) is noticably less than that for the pathologic APGAR scores (for normal birth weight in- fants APGAR scores between 1 and 7 were coded between $6.5 \%$ and $25 \%$ ).

Thus the variance for birth weights which as an objectively measured criteria is noticably less than that for the APGAR socre which contains a subjective assessment. These discrepancies increase if criteria are regarded with almost exclusively subjective classification (Tabs. IV and V). In Tab. IV we listed abnormal findings for low birth weight infants where the variance of the frequencies exceeds a factor of 10 . For mature newborns this variance is usually only five-fold and only for the two items \#1 and \#6 in Tab. V palmor (grasp 
Tab. III. Differences among the various institutions.

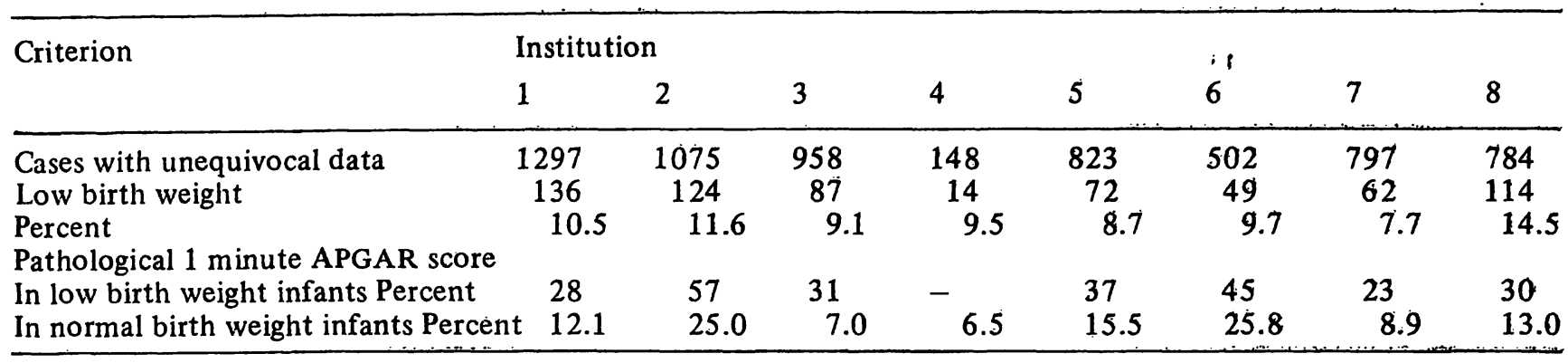

Tab. IV. Differences in the recording of pathological findings in low birth weight newborns (Percent).

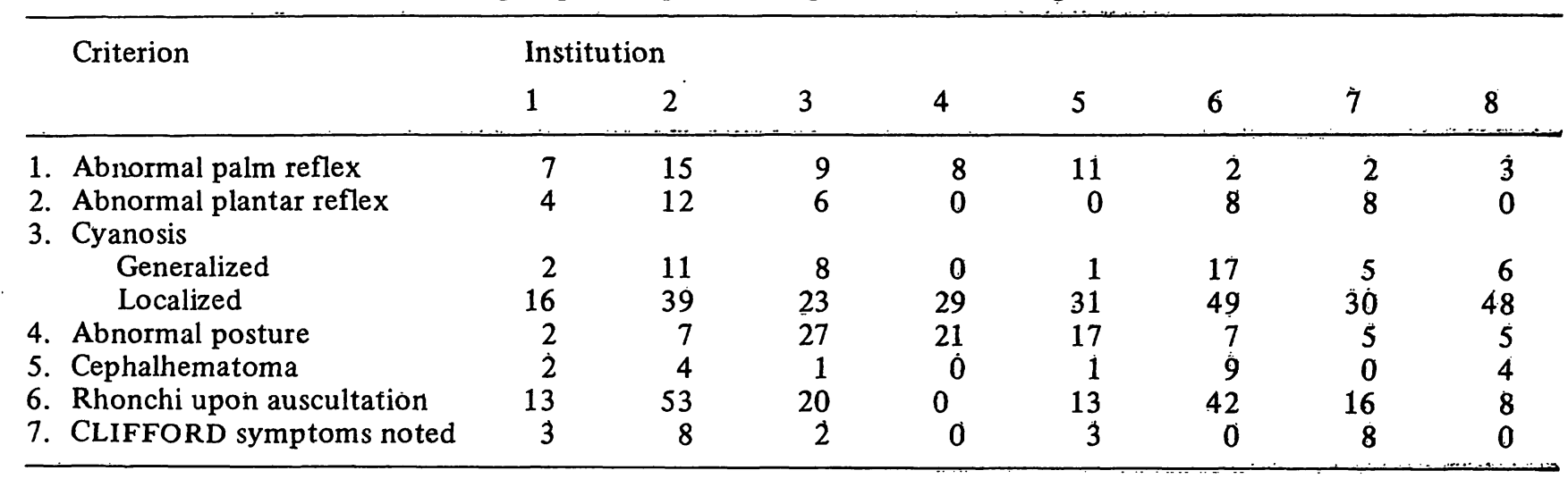

Tab. V. Differences in the recording of pathological finding̀s in normal birth weight infants (percent).

\begin{tabular}{lrrrrrrrr}
\hline Criterion & \multicolumn{3}{c}{ Institution } & & & & & \\
& 1 & 2 & 3 & 4 & 5 & 6 & 7 & 8 \\
\hline 1. Abnormal palm reflex & 2.4 & 5.2 & 2.5 & 1.6 & 2.6 & 3.4 & 3.0 & 0.2 \\
2. Abnormal plantar reflex & 1.5 & 1.7 & 1.9 & 1.5 & 1.9 & 0.5 & 2.0 & 0.4 \\
3. Cyanosis & & & & & & & & \\
$\quad$ Generalized & 1.0 & 1.1 & 1.2 & 0 & 0.4 & 0.2 & 0.7 & 0.3 \\
$\quad$ Localized & 10.9 & 9.0 & 22.8 & 8.2 & 20.6 & 5.1 & 12.1 & 6.3 \\
4. Abnormal posture & 1.7 & 2.7 & 3.8 & 0.7 & 0.9 & 0.7 & 1.7 & 1.1 \\
5. Cephalhematoma & 2.9 & 2.3 & 4.3 & 3.8 & 2.8 & 4.4 & 2.9 & 1.3 \\
6. Rhonchi upon auscultation & 3.9 & 11.4 & 5.0 & 0 & 1.1 & 1.8 & 2.0 & 1.1 \\
7. CLIFFORD symptoms noted & 2.9 & 9.5 & 9.0 & 12.2 & 16.4 & 2.4 & 8.0 & 2.3 \\
\hline
\end{tabular}

reflex and rhonchi upon anscultation) is the variance higher, reaching a factor of 10 .

\section{Discussion and conclusion}

The frequency of errors in epidemiologic studies relates to coding errors. Errors from electronic data processing can be ignored because of their low number. Coding errors depend largely on:

1.) the preciseness of coding instructions
2.) the possibility to obtain data as independent as possible from personal bias

3.) the organization of computer cards and the corresponding key; i.e., key and cards should not be separated; it must not be allowed that coding fields left blank; i.e., in all coding fields an indication must be marked, the predicates "none" or "not existing" or" "not applied" always should be coordinated with " 0 ". Good legibility and a simplè structure are also importañt. 
4.) It should be possible to check coded data from other documents.

5.) Controls should be provided.

These five items require two pre-requisites, namely, the personal experience of the investigator and the use of economical resources. These decisions are those of the funding organization. Preferably the direction of such a project should be in the hands of a staff who already have collaborated on earlier large epidemiological studies.

Kovacs et al. [5] have shown how an increase of personnel time per coded item leads to fewer coding errors. In a study similar to ours the total error rate was decreased from an initial $1.48 \%$ to $0.96 \%$ by the use of additional controls and training.

Model computations have shown that if significance is tested with the Chi-square test and if there is a $5 \%$ error rate in the data material and an additional $5 \%$ probability of errors when comparing groups of over 2000 cases each, the trend of a statement is not affected.

The large differences in the classification of abnormal findings between various institutions, especially when instead of measured values less clearly defined terms must be used, demonstrate the importance of allowing for the variability of views in the final evaluation. We do not think that data of participating institutions should be eliminated because the large differences in diagnoses and therapy are real and otherwise the study would not reflect reality. We also wish to discourage the tendency to reject or underestimate the validity of statistical studies on the basis of their error rate. The information regarding errors should only serve to weight the degree of certainty of epidemiological statements. The selection criteria which embody the scientific basis for any study usually play a larger role than the errors in the obtaining of data. Therefore, we recommend not to consider as absolute the results of any single study no matter how large and how "highly significant" (!) nor to use them as sole basis for planning, allocation of resources, or the setting of therapic standards. This can only be done after the results of several studies concur and offer the necessary certainty.

\section{Summary}

Large epidemiological studies with over 5000 cases have the advantage of providing sufficient case numbers for the statistical evaluation of sub-groups. They are associated with a higher error rate in data collection and the influence of differences in judgment on part of the collaborators. In order to quantitatively assess these problems two studies were performed with data material from the research project "Perinatology" in the German Democratic Republic. This project investigated questions of epidemio- logy of newborns at risk in the years 1970 to 1972 in eight medical institutions with a total of 6780 cases.

1.) By comparing the original hospital records of 310 cases the errors for 33 criteria in the computer printout were determined.

2.) For 7 subjective clinical criteria in the newborn the difference in opinions was demonstrated by determining the frequency of abnormal findings in the various institutions.

\section{Results}

The overall error rate was relatively high with $8.8 \%$ (Tab. I). Of these, $4.3 \%$ can be eliminated for the evaluation by reducing the case numbers by this percentage. In Tab. II errors are correlated with the criteria in which they were found. Further discussion is limited to those criteria for which the error rate exceeded $5 \%$. For errors which can be eliminated criterion \#33: "administration of antibiotics to the newborn" appeared least favorable because a rate of $95.6 \%$ of missing data prevented this criterion from being evaluated.

In regard to errors which cannot be eliminated, one can summarize that they were distributed in essence to 7 criteria accounting for $21 \%$ of the 33 criteria tested. For 6 of the 7 criteria (\#29: position and presentation of the fetus during birth: \#30: fever during birth; \#26: onset of labor; \#27: quality of concentrations; $\# 19$ : number of previous births; \#20: toxemia of pregnancy) evaluation was influenced by the coded errors. For criteria 9: "Occupation of the mother" a specific interview yielded a greater accuracy for the study than was found in the hospital record.

The differences in the frequency of abnormal findings in the different institutions is tabulated in Tabs. III $-V$. The rate of low birth weight infants varies between institu- 
tions less (only two-fold between $7.7 \%$ and $14.5 \%$ ) than clinical findings for all the newborns which varied by a factor of 5-10 between the hospitals.

\section{Discussion and conclusion}

Computer models show that 5\% coding errors (noneliminable errors) do not change the trend of a statistical statement if the sub-sets compared contain several thousand cases. A psychologically favorably design of the coding material is especially important.

By increasing the effort per variable investigated the error rate may be decreased substantially [5] but this either raises the cost or the number of cases must be decreased. The experience of the principal investigator in such a study will lead to a decision as to the best use of the resources.

Keywords: Epidemiology, errors in data collection, perinatology.
This shows that the difference in the number of abnormal findings between institutions is not a consequence of the selection of newborns for the study itself but rather a consequence of differences in judgments.
Differences in the evaluation of abnormal findings by various collaborators which persist after standardization and joint discussions should be retained as reflecting the actual state of knowledge and should not be eliminated in retrospect by "adjustments." The estimation of errors in epidemiologic studies should serve to indicate the reliability of the statements but they should not cause irrelevant global value judgements.

\section{Zusammenfassung}

Zur Fehlerhäufigkeit innerhalb umfangreicher epidemiologischer Studien mit Schlußfolgerungen für Auswertpraxis, Ergebnisinterpretation und neue Erhebungen.

Umfangreiche epidemiologische Studien mit über 5000 Fällen haben den Vorteil, für statistische Auswertungen von Untergruppen noch ausreichend Fälle zur Verfügung zu stellen. Einher gehen damit allerdings eine höhere Fehlerrate in der Datenerfassung und das Einfließen unterschiedlicher Auffassungen der Mitarbeiter. Um diese Probleme quantitativ abschätzen zu können, wurden 2 Untersuchungsgänge am Datenmaterial des Forschungsprojekts „Perinatologie“ der DDR durchgeführt, das u.a. eine Erhebung žur Epidemiologie des Risikoneugeborenen der Jahre 1970 bis 1972 von 8 medizinischen Einrichtungen mit insgesamt 6780 Fällen enthält.

1. Von 310 Fällen wurden für $33 \mathrm{Kriterien} \mathrm{durch} \mathrm{Ver-}$ gleich mit den Krankenjournalen die Fehler im Computerausdruck ermittelt.

2. Von 7 Kriterien, bei denen es sich um subjektiv beurteilte klinische Befunde des Neugeborenen handelt, werden zur Demonstration unterschiedlicher Auffassungen die Häufigkeiten abnormer Befunde getrennt nach den medizinischen Einrichtungen publiziert.

\section{Ergebnisse}

Die Gesamtfehlerrate erscheint mit $8,8 \%$ (Tab. I) relativ hoch. Davon lassen sich jedoch 4,3\% bei der Auswertung eliminieren durch Reduzieren des Fallmaterials um diesen Prozentsatz. In der Tab. II sind die Fehler den Kriterien zugeordnet, bei denen sie gefunden wurden. Zur Besprechung gelangen nur die Kriterien, bei denen die Fehlerrate über 5\% liegt. Bezüglich der eliminierbaren Fehler ist das Kriterium 33: „Antibiotikagabe an das Neugeborene“ am ungünstigsten betroffen, da durch eine Rate von 95,6\% fehlender Angaben dieses Kriterium nicht ausgewertet werden kann.

Bezüglich der nicht eliminierbaren Fehler kann man zusammenfassend sagen, daß sie sich im wesentlichen auf 7 Kriterien verteilen, das sind $21 \%$ der 33 getesteten $\mathrm{Kri-}$ terien. Bei 6 dieser 7 Kriterien (Kriterium 29: Lage und Einstellung des Fetus unter der Geburt, Kriterium 30: Fieber unter der Geburt, Kriterium 26: Ingangkommen der Geburt, Kriterium 27: Qualität der Wehentätigkeit, Kriterium 19: Anzahl der vorausgegangenen Geburten,
Kriterium 20: Spätgestose der Schwangeren) wird die Auswertung durch die codierten Fehler eingeschränkt. Bei dem Kriterium 9: ,Beruf der Mutter“ ist durch gezieltes Befragen eine größere Genauigkeit durch die Erhebung in der Studie erreicht worden als im Krankenjournal.

Die unterschiedlichen Häufigkeiten erhobener abnormer Befunde in den verschiedenen medizinischen Einrichtungen sind in den Tab. III-V dargestellt. Die Rate untergewichtig geborener Kinder schwankt zwischen den Einrichtungen viel weniger (nur um das Doppelte, zwischen $7,7 \%$ und $14,5 \%$ ) als die klinischen Befunde bei den Neugeborenen, deren Schwankungsbreite zwischen den Kliniken sich auf das 5-fache bis 10-fache beläuft.

Das zeigt, daß die unterschiedlichen Häufigkeiten abnormer Befunde zwischen den medizinischen Einrichtungen nicht eine Folge der Auswahl der Neugeborenen für das Studienprogramm sein können, sondern eịne Folge unterschiedlicher Bewertungen sind. 


\section{Diskussion und Schlußfolgerungen}

Wie uns Modellrechnungen gezeigt haben, verändern 5\% falsche Codierungen (nicht eliminierbare Fehler) den Trend einer statistischen Aussage nicht, wenn die zu vergleichenden Untergruppen noch mehrere tausend Fälle beinhalten. Auf eine psychologisch gute Gestaltung der Datenträger ist besonderer Wert zu legen.

Durch Erhöhung des Zeitaufwandes pro untersuchtes Merkmal läßt sich zwar die Fehlerrate erheblich senken [5], dadurch steigt aber der ökonomische Aufwand stark an oder aber die Fallzahl muß geringer gehalten werden. Wie man die Kräfte für eine solche Erhebung am besten einteilt, wird ein erfahrener Leiter nach der konkreten
Fragestellung bemessen, auf die die Studie eine Antwort geben soll.

Unterschiede der Bewertung abnormer Befunde durch verschied ene Mitarbeiter, die sich auch nach gemeinsamer Beratung oft noch einschleichen, sollten als Widerspiegelung des aktuellen Kenntnisstandes gewertet werden und nicht retrospektiven „Materialbereinigungen“ zum Opfer fallen.

Fehlerabschätzungen epidemiologischer Studien sollen die Zuverlässigkeit der Aussagen präzisieren, aber nicht der Anlaß für unsachliche pauschale Werturteile sein.

Schlüsselwörter: Epidemiologie, Fehler bei der Datenerhebung, Perinatologie.

\section{Résumé}

Du taux d'erreur dans les vastes études épidémiologiques avec conclusions quant à l'aspect pratique, l'interprétation des résultats et les données nouvelles

Les études épidémiologiques s'adressant à plus de 5000 cas ont l'avantage de mettre à disposition encore suffisamment de cas pour l'analyse statistique de sous-groupes. Elles impliquent cependant un taux plus élevé d'erreurs dans la collecte des données ainsi que la confluence de divers avis des collaborateurs. Afin d'apprécier quantitativement ces Problèmes nous avons entrepris deux modes d'analyse des données du projet de recherche «Périnatologie» de la RDA, qui comprend entre autres un recueil épidémiologique des nouveaux-nés à haut risque entre les années 1970 et 1972 des établissements hospitaliers avec un total de 6780 cas.

1. Dans 310 cas nous avons comparé à l'aide de 33 critères les erreurs entre dossiers médicaux et dates d'ordinateur. 2. Quant à 7 critères où il était question de données subjectives chez le nouveau-né, nous avons prouvé les conceptions divergentes selon les différents centres.

\section{Résultats}

Le taux global d'erreur semble être, avec $8.8 \%$ (Tab. I) relativement élevé. Cependant l'on peut éliminer $4.3 \%$ des erreurs par réduction du collectif. Dans le Tab. II nous avons classé les erreurs selon les critères de constantation. Nous avons retenu pour la discussion seulement des critères comprenant des erreurs allant au dessus de $5 \%$. C'est le critère 33 «administration d'antibiotiques au nouveauné» qui est le plus touché car ce critère ne peut être analysé, $95,6 \%$ des données étant manquantes.

En résumé l'on peut dire que les erreurs non éliminables se répartissent principalement sur 7 critères, soit $21 \%$ de l'ensemble des 33 critères testés. L'erreur codée limite 6 de ces 7 critères, soit nr 29 (présentation et position du foetus pendant l'accouchement), nr 30: (fièvre pendant l'accouchement), nr 26 (déclanchement de l'accouchement), nr 27 (qualité des contractions), nr 20 (toxémie gravidique tardive).

\section{Discussion et conclusions.}

Nos calculs-type ont montré que $5 \%$ de fausses codifications ne modifient guère la tendance d'un fait statistique (erreurs non éliminables), et ceci lorsque les sous-groupes à comparer comportent encore plusieurs milliers de cas. Il faut veiller à une présentation soignée des porteurs de dates.

L'élévation du temps consacré à l'étude par critère abaisse le taux d'érreur considérablement [5]mais le coût en aug-
Grace à un interrogatoire plus précis l'étude a fourni une exactitude supérieure que les données des dossiers hospitaliers en ce qui concerne le critère 9: profession maternelle.

Dans les tableaux III à $\mathbf{V}$ nous représentons les diverses fréquences selon les centres, quant aux constatations divergentes des anomalies. Le taux de poids faibles à la naissance ne varie entre les établissements que du simple au double (7.7\% à $14.5 \%$ ), alors que les données neonatales cliniques peuvent varier de cinq à dix fois.

Ceci montre que les variations de taux des constatations anormales entre les divers établissements hospitaliers ne sont point le fait du choix des nouveaux-nés pour cette étude, mais d'appréciations différentes.

mente d'autant ou bien il faut réduire le nombre des cas. L'organisateur éclairé aura à trancher quant à la répartition des forces disponibles pour l'analyse d'un fait concret. Les différences d'appréciation des donnèes anormales selon les différents collaborateurs d'une étude, qui peuvent survenir même après des délibération en commun, ne doivent être pris que comme l'éffet des connaissances 
actuelles et ne devraient pas être victime de «nettoyages de matériel retrospectifs».

L'appréciation des érreurs des études épidémiologiques devraient préciser la fiabilité des constatations mais ne devraient pas constituer Poccasion d'émettre de jugements éronnés globaux.

Mots-clés: Epidémiologie, erreurs au cours de relevé de données, périnatologie.

* Acknowledgement: These investigations were performed within the study project Perinatology (project director: Dr. sc. med. L. GRAUEL), subproject Epidemiology (project director: Dr. sc. med. H. EGGERS) of the Ministry for Health of the German Democratic Republic.

\section{Bibliography}

[1] AKKERMANN, S., H. EGGERS, H.-U. GÜLZOW, E. P. ISSEl, R. Kellner, C. Plath, R. Plesse, B. SCHOLZ, J. TÖWE: Fragebogen zur Erfassung der soziologischen und klinischen Problemsituation der Risikoneugeborenen. Abteilung Wissenschaftspublizistik der Universität Rostock, Rostock 1971

[2] EgGERS, H., C. PLATH, E. P. ISSEL, S. AKKERMANN, H.-U. GÜLZOW, W. HOEPFFNER, E. KOEPCKE, L. LADSTÄTTER, A. NIEDNER, R. PLESSE, K. REIS, M. RISSMANN, R. SCHNEIDER: VOIGT, S. SCHÖNE, B. SEIFERT, R. THIEME, J. TÖWE, M. VOIGT, K. WUNDERLICH: Perinatale Risikofaktoren - Eine epidemiologische Studie. 1. Mitteilung. Dtsch. Ges.wesen 30 (1975) 966. Epidemiologische Zusammenhänge zwischen sozialen Risikofaktoren Schwangerschaftsverlauf und niedrigem Geburtsgewicht. 3. Mitteilung. Dtsch. Ges.wesen 31 (1976) 1926

[3] ISSEL, E. P., H. EgGers, C. Plath, S. AKKERMANN, H.-U. GÜLZOW, W. HOEPFFNER, E. KOEPCKE, L. LADSTÄTTER, A. NIEDNER, R.
PLESSE, K. REIS, M. RISSMANN, R. SCHNEIDERVOIGT, S. SCHÖNE, B. SEIFERT, R. THIEME, J. TÖWE, M. VOIGT, K. WUNDERLICH: Perinatale Risikofaktoren - Eine epidemiologische Studie. Beziehungen zwischen postnatalem Zustand des Neugeborenen (APGAR-Wert) und anderen perinatalenParametern. 2. Mitteilung. Dtsch. Ges.wesen 30 (1975) 2065

[4] ISSEL, E. P., J. TÖWE, Z. KOVÁCS, B. DUDÁS, F. PLATH: Die Bedeutung des Vergleichs epiderniologischer Arbeiten zwischen verschiedenen Ländern und die Lösung dabei auftretender Schwierigkeiten auf dem Gebiet der Perinatologie. Dtsch. Ges.wesen 29 (1974) 873

[5] KOVÁCS, Z., ISSEL, E. P., OBÁL, M., DUDÁS, B. TÖWE, J.: Observation concerning perinatal epidemiological investigations. In: STEMBERA, Z. K.: Perinatal Medicine. 4th European Congress of Perinatal Medicine, Prague, August 1974. Thieme, Stuttgart 1975

Received March 27, 1980. Revised June 26, 1980. Ac cepted August 19, 1980.

Dr. med. E. P. Issel

Univ.-Frauenklinik

Tucholskystraße 2

DDR-104 Berlin 